Report to Congress in

Response to Public Law 99-240

\title{
Summary of Expenditures of Rebates from the Low-Level Radioactive Waste Surcharge Escrow Account for Calendar Year 1990
}

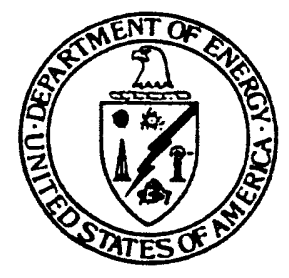

\author{
U.S. Department of Energy \\ Office of Environmental Restoration \\ and Wiste Management
}

June 1991 
This report has been reproduced directly from the best available copy.

Available to DOE and DOE contractors from the Office of Scientific and Technical Information, P.O. Box 62, Oak Ridge, TN 37831; prices available from (615) 576-8401, FTS 626-8401.

Available to the public from the National Technical Information Service, U.S. Department of Commerce, 5285 Port Royal Rd., Springfield, VA 22161. 
The Secretary of Energy

Washington, DC 20585

August 16, 1991

DOE/EM--0057P

DE 92002628

The Honorable Dan Quayle

President of the Senate

Washington, D.C. 20510

Dear Mr. President:

Enclosed is the fifth in a series of annual reports prepared for the Congress entitled "Summary of Expenditures of Rebates from the Low-Level Radioactive Waste Surcharge Escrow Account for Calendar Year 1990."

The Department of Energy (DOE) submits this report in compliance with section $5(\mathrm{~d})(2)(E)$ of Public Law 99-240, the "Low-Level Radioactive Waste Policy Amendments Act of 1985" (the Act). Section $5(d)(2)(E)$ al so specifies how rebates from the surcharge escrow account may be used by States and compacts in developing new low-level radioactive waste disposal capacity. Within these constraints, some current and planned activities of States and compacts are predicated upon receipt of the surcharge rebates. date, a total of approximately $\$ 15 \mathrm{million}$ has been disbursed under this program to the States and compacts following the 1986, 1988 , and 1990 milestones. We estimate that an additional $\$ 18$ million in surcharge rebates is projected to be available for disbursement in connection with the 1993 milestone. About

$\$ 4.3 \mathrm{milli}$ ion of these funds were expended by the States and compacts during calendar year 1990 for work on low-level waste management activities.

Recipients of the rebates are required by the Act to provide the DOE an expenditure report at the end of each year in which any of the rebated funds are expended. The DOE analyzes these reports in terms of the expenditure requirements that are defined in the Act. As reflected in the enclosed report, the DOE has reviewed each of the reported expenditures by the States and compacts in 1990 and concluded that they comply with the spending requirements in the Act.

Preparation of this report is one of several responsibilities assigned to the DOE by the Congress. Section $7(b)$ of the Act requires that the DOE provide Congress with an annual report summarizing progress of the states and compacts in developing new disposal capacity and managing low-level radioactive waste. This report is currently being prepared and should be submitted to the Congress on or about September $30,1991$. 
The States are activo?y engaged in pursuing the requirements under the Act and maintain the authority to implement the processes necessary to be in compliance with the Act. This year's annual progress report to Congress, however, will conclude that cont inued delays are evident in the States' schedules to meet the Act's January 1992 milestone, the January 1993 deadline for providing disposal capability, and the January 1996 final target date.

At the time this report is submitted to the Congress, nine regional interstate compacts covering 43 States have been ratified by Congress to meet the purposes of the Act. The remaining seven States, the District of Columbia, and Puerto Rico are not affiliated with a regional compact. Of 14 new disposal sites planned, DOE believes that only two sites are in a position to meet the 1993 deadline for providing disposal capability for low-level waste. A number of States that do not expect to have disposal capability by 1993 reported in 1990 that they intend to rely on storage as the primary means of managing low-level radioactive waste until disposal capacity becomes available. We estimate that as much as 80 percent of the Nation's low-level radioactive waste generated by Nuclear Regulatory Commission and Agreement State licensees would require such interim storage. To assure the future availability of adequate low-level waste. disposal capacity, States and compacts need to accelerate negotiations among themselves, since it appears some will not meet the requirements identified in the Act. This portrays a less-than-optimistic view on the future ability of the States to meet the requirements of the Act. A more extensive discussion of this situation will be provided in the annual report the DOE submits to comply with section 7 (d) of the Act.

The Department pledges continued support to the States and compacts in their efforts to develop new low-level radioactive waste disposal facilities.

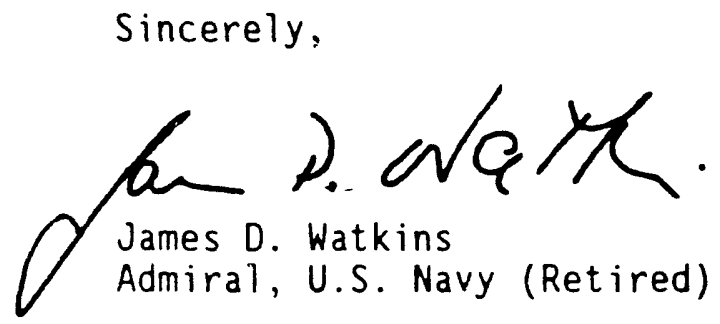

Enclosure 


\section{ADDRESS LIST}

The Honorable Dan Quayle President of the Senate Washington, D.C. 20510

The Honorable J. Bennett Johnston Chairman

Committee on Energy and Natural Resources

United States Senate

Washington, D.C. 20510

The Honorable Malcolm Wallop

Ranking Minority Member

Committee on Energy and Natural Resources

United States Senate

Washington, D.C. 20510

The Honorable Quent in N. Burdick

Chairman

Committee on Environment and Public Works

United States Senate

Washington, D.C. 20510

The Honorable John $H$. Chafee

Ranking Minority Member

Committee on Environment

and Public Works

United States Senate

Washington, D.C. 20510

The Honorable Joseph R. Biden, Jr.

Chairman

Committee on the Judiciary

United States Senate

Washington, D.C. 20510

The Honorable Jack Brooks

Chairman

Committee on the Judiciary

U.S. House of Representatives

Washington, D.C. 20515
The Honorable Thomas S. Foley

Speaker of the

House of Representatives

Washington, D.C. 20515

The Honorable John D. Dingell

Chairman

Committee on Energy and Commerce

U.S. House of Representatives

Washington, D.C. 20515

The Honorable Norman F. Lent

Ranking Minority Member

Committee on Energy and Commerce

U.S. House of Representatives

Washington, D.C. 20515

The Honorable George Miller

Chairman

Committee on Interior and Insular Affairs

U.S. House of Representatives

Washington, D.C. 20515

The Honorable Don Young

Ranking Minority Member

Committee on Interior

and Insular Affairs

U.S. House of Representatives

Washington, D.C. 20515

The Honorable Strom Thurmond

Ranking Minority Member

Committee on the Judiciary

United States Senate

Washington, D.C. 20510

The Honorable Hamilton Fish, Jr.

Ranking Minority Member

Committee on the Judiciary

U.S. House of Representatives

Washington, D.C. 20515 


\section{Report to Congress in Response to Public Law 99-240}

\section{Summary of Expenditures of Rebates from the Low-Level Radioactive Waste Surcharge Escrow Account for Calendar Year 1990}

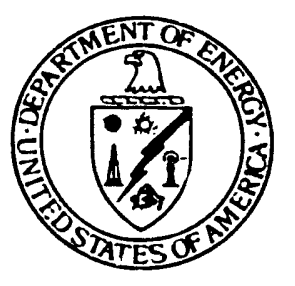

U.S. Department of Energy Office of Environmental Restoration and Waste Management Washington, D.C. 20585

\section{June 1991}




\section{EXECUTIVE SUMMARY}

This is the fifth report submitted to Congress under Title I, section 5(d)(2)(E) of Public Law 99-240, "The Low-Level Radioactive Waste Policy Amendments Act of 1985" (the Act). This section of the Act requests the Department of Energy (DOE) to summarize the annual expenditures of funds disbursed from the DOE surcharge escrow account and to assess compliance of these expenditures with the specified limitations.

The Act places limitations on the use of these funds and requires the nonsited compact regions and nonmember States to provide DOE with an itemized report of their expenditures on December 31 of each year in which funds are expended. Within 6 months after receiving the individual reports, DOE is to furnish Congress a summary of the reported expenditures and an assessment of compliance with the limitations on the use of these funds specified in the Act. This report fulfills that requirement.

DOE disbursed funds totaling $\$ 15,006,587.76$ to the States and compact regions following the July 1, 1986, January 1, 1988, and January 1, 1990, milestones. Of this amount, $\$ 4,328,340.44$ was expended during calendar year 1990 and $\$ 2,239,205.80$ was expended during the prior 4 years. At the end of December 1990, $\$ 8,439,041.52$ was unexpended.

DOE has reviewed each of the reported expenditures and concluded that all reported expenditures comply with the spending limitations stated in section $5(d)(2)(E)(i)$ of the Act. 
EXECUTIVE SUMMARY . . . . . . . . . . . . . . . . . . . . . . . . . . . .

1. INTRODUCTION . . . . . . . . . . . . . . . . . . . . . . . . . . . . 1

2. 1986, 1988, AND 1990 MILESTONE REBATES . . . . . . . . . . . . . . . 3

2.1 Rebate Eligibility . . . . . . . . . . . . . . . 3

2.2 Rebate Disbursements . . . . . . . . . . . . . . . 5

3. SUMMARY OF SURCHARGE REBATE EXPENDITURES DURING 1990 . . . . . . . . . 8

3.11990 Surcharge Rebate Expenditures By Nonsited Compact Regions . 8

3.21990 Surcharge Rebate Expenditures By Nonmember States . . . . . 12

4. SUMMARY OF EXPENDITURES (1986-1990) . . . . . . . . . . . . . . . . . 14

\section{TAPLES}

1. SUMMARY OF MILESTONE COMPLIANCE DETERMINATIONS . . . . . . . . . . . . . . 4

2. $1986,1988,1990$ MILESTONE DISBURSEMENT SUMMARY . . . . . . . . . . . 6

3. 1990 EXPENDITURES BY EXPENSE CATEGORY . . . . . . . . . . . . . . . . . . . . 9

4. SUMMARY OF EXPENDITURES BY YEAR (1986-1990). . . . . . . . . . . . . . 15

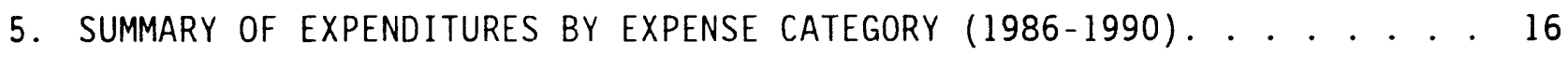




\section{SUMMARY OF EXPENDITURES OF REBATES FROM THE LOW-LEVEL RADIOACTIVE WASTE SURCHARGE ESCROW ACCOUNT FOR \\ CALENDAR YEAR 1990}

\section{INTRODUCTION}

This report is submitted in response to the Low-Level Radioactive Waste Policy Amendments Act of 1985 (the Act), Public Law 99-240. The report summarizes expenditures made during calendar year 1990 of surcharge rebates from the July 1, 1986, January 1, 1988, and January 1, 1990, milestones.

Title I of the Act requires the Department of Energy (UOE) to administer a surcharge escrow account. This account consists of a portion of the surcharge fees paid by generators of low-level radioactive waste in nonsited compact regions (compact regions currently without disposal sites) and nonmember States (States without disposal sites that are not members of compacts) to the three States with operating disposal facilities (Nevada, South Carolina, and Washington - - sited States) for using their disposal facilities. In administering the surcharge escrow account, the Act requires DOE to:

- Invest the funds in interest-bearing United States Government securities;

- Determine eligibility for rebates of the funds by evaluating compact region and State progress toward developing new disposal sites against milestone requirements set forth in the Act;

- Disburse the collected rebates and accrued interest;

- Assess compliance of rebate expenditures with the limitations prescribed in the Act;

- Submit a report annually to Congress summarizing rebate expenditures by States and compact regions.

Section 5(d) of the Act authorized the three sited States to coliect surcharges on waste that was received at their facilities and generated in nonsited compact regions and nonmember States. Low-level waste generators in sited regions are exempt from these surcharges. Twenty-five percent of the surcharges collected by the sited States from waste generators in the nonsited compact regions and nonmember states is transferred monthly to the DOE surcharge escrow account.

DOE is required to disburse the deposited funds, with accrued interest, to each nonsited compact region and nonmember state that DOE has determined to be in compliance with the milestone requirements of the Act. If DOE determines that a nonsited compact region or nonmember State is not in compliance with the milestone requirements, its funds are returned to the sited State(s) in which the funds were collected. 
Section $5(d)(2)(E)(i)$ of the Act specifies that nonsited compact regions and nonmember States may use funds from the DOE surcharge escrow account only to:

"(I) establish low-level radioactive waste disposal facilities;

(II) mitigate the impact of low-level radioactive waste disposal facilities on the host State;

(III) regulate low-level radioactive waste disposal facilities; or

(IV) ensure the decommissioning, closure, and care during the period of institutional control of low-level radioactive waste disposal facilities."

Section $5(d)(2)(E)(i i)(I)$ requires that nonsited compact regions and nonmember States receiving rebates:

". . shall, on December 31 of each year in which any such funds are expended, submit a report to the Department of Energy itemizing any such expenditures."

Section $5(d)(2)(E)(i i)(I I)$ further requires that:

"Not later than six months after receiving the reports (submitted by nonsited compact regions and nonmember Status)... the Secretary shall suimit to the Congress a summary of all such reports that shall include an assessment of the compliance of each such State or compact commission with the requirements of clause (i)." (1imitations on uses of rebate payments).

On June 24, 1986, DOE issued a Federal Register Notice entitled "Implementation of Procedures for DOE's Management of the Low-Level Radioactive Waste Surcharge Escrow Account." This notice described the following:

- Procedures used by the sited States to transfer surcharge funds to the Department of Energy for deposit into the surcharge escrow account;

- Procedures that apply to the Department's determination to disburse money from the surcharge escrow account;

- Procedures used by the nonsited compact regions and nonmember States to report to the Department of Energy their expenditures of funds from the surcharge escrow account.

This report and the four prior rebate expenditure reports are based on information provided to DOE by States and comp.ct regions in response to the reporting procedures in the notice. 
2. 1986,1988 , AND 1990 MILESTONE REBATES

\subsection{Rebate Eligibility}

The first milestone, section $5(e)(1)(A)$ of the Act, required that:

"By July 1, 1986, each such non-member State shall ratify compact legislation or, by the enactment of legislation or the certification of the Governor, indicate its intent to develop a site for the location of a low-level radioactive waste disposal facility within such State."

Following the first milestone, DOE found six compact regions $(22$ member States) and six nonmember States eligible to receive surcharge rebates, two States ineligible, and three states not subject to evaluations by DOE because no funds attributed to their generators had been deposited in the surcharge escrow account.

The second milestone, section $5(e)(1)(B)$ of the Act, required that by January 1, 1988, each nonmember State would develop a siting plan and delegate authority to implement the plan. In addition, "...each non-sited compact region shall identify the State in which its low-level radioactive waste disposal facility is to be located, or shall have selected the developer for such facility and the site to be developed...."

Following the second milestone, DOE found six compact regions (22 member States) and seven nonmember States eligible to receive surcharge rebates, three States ineligible, and one Siate not subject to evaluations by DOE because no funds attributed to its generators had been deposited in the surcharge escrow account.

The third milestone, section $5(\mathrm{e})(1)(C)$ of the Act, required each host State to submit by January 1, 1990, a complete disposal facility license application. As an alternative, the Act allowed the Governor of each State not in a sited compact region to provide a written certification to the Nuclear Regulatory Commission stating, "that such State will be capable of providing for, and will provide for, the storage, disposal, or management of any low-level radioactive waste generated within such State and requiring disposal after December 31, 1992, and include a description of the actions that will be taken to ensure that such capacity exists."

Following the third milestone, DOE found six compact regions (24 member States) and six nonmember States eligible to receive surcharge rebates, and three states not subject to evaluations by DOE because no funds attributed to their generators had been deposited in the surcharge escrow account.

The 19 member States of the three sited compact regions (Northwest, Rocky Mountain, Southeast) were not subject to the requirements of any milestone.

These determinations are summarized in Table 1. 
TABLE 1. SUMMARY OF MILESTONE COMPLIANCE DETERMINATIONS

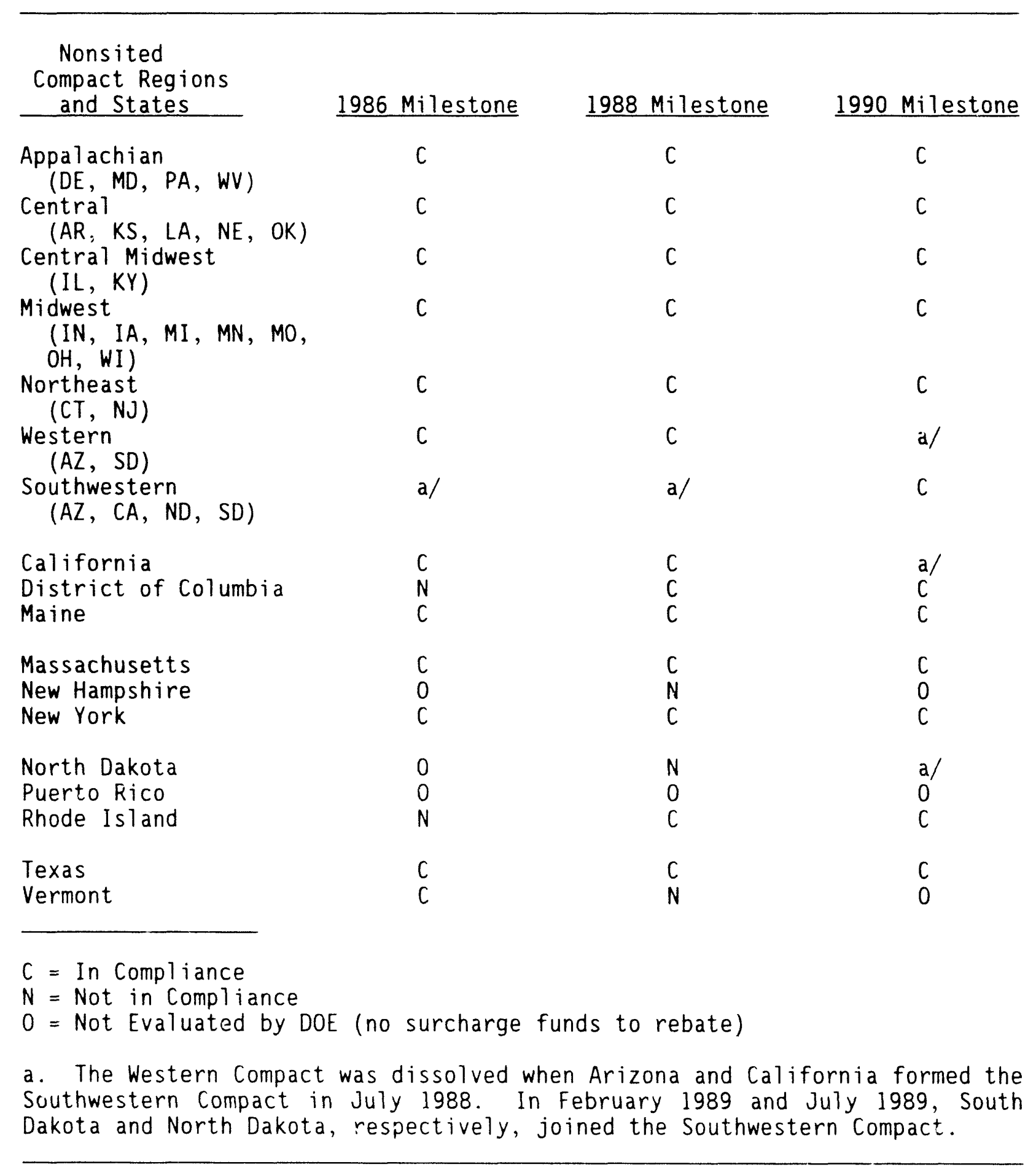




\subsection{Rebate Disbursements}

At the end of the July 1, 1986, milestone period (January 1, 1986, through JuTy 1, 1986), deposits from the three sited States to the DOE surcharge escrow account (and accrued interest) totaled \$921,987.22. After making its milestone determinations, DOE disbursed $\$ 910,544.78$ to the eligible nonsited compact regions and nonmember States as shown in Table 2. Of the remaining $\$ 11,442.44$, DOE retained $\$ 1,162.36$ in the escrow account at the request of Delaware because its compact region, the Appalachian, had not yet convened a compact commission to receive the funds; $\$ 10,280.08$ was returned to the sited States either because the money was collected from sited compact region generators and deposited in the surcharge escrow account in error or the State that originally paid the surcharge was determined to be ineligible to receive rebates.

At the end of the January 1, 1988, milestone period (July 2, 1986, through January 1, 1988), deposits from the three sited States to the DOE surcharge escrow account (and accrued interest) totaled $\$ 4,467,279.16$. After making its milestone determinations, DOE disbursed $\$ 4,413,825.33$ to eligible nonsited compact regions and nonmember States as shown in Table 2. Of the remaining $\$ 53,453.83$, DOE retained $\$ 7,800.85$ in the escrow account at the request of Delaware, West Virginia, and South Dakota because their compact regions, the Appalachian and Western (later dissolved and reformed into the Southwestern Compact Region), respectively, had not yet convened compact commissions to receive the funds, and $\$ 45,652.98$ was returned to the sited States either because the money was collected from sited compact region generators and deposited in the surcharge escrow account in error or the state that originally paid the surcharge was determined to be ineligible to receive rebates.

At the end of the January 1, 1990, milestone period (January 2, 1988, through January 1, 1990), deposits from the three sited States to the DOE surcharge escrow account (and accrued interest) totaled $\$ 9,716,905.94$. After making its milestone determinations, DOE disbursed $\$ 9,682,217.65$ to eligible nonsited compact regions and nonmember States as shown in Table 2 . Of the remaining $\$ 34.588 .29$, DOE retained $\$ 28,659.05$ in the escrow account at the request of Celaware, West Virginia, and South Dakota because the commissions of their compact regions, the Appalachian and Southwestern, respectively, had not yet made the necessary provisions to receive the funds; $\$ 6,029.24$ was returned to the sited State of South Carolina because the money was collected from generators in Maine during a period of noncompliance as determined by the sited States. (NOTE: Additional funds attributable to Maryland and Pennsylvania deposited in the surcharge escrow account after disbursement of the January 1, 1990, rebates are being held in the escrow account at the request of the Appalachian Compact Commission.)

A total of $\$ 15,006,587.76$ for the three milestones was disbursed to the nonsited compact regions and nonmember States as shown in Table 2 . Funds attributable to the States of Delaware, West Virginia, and South Dakota are being held in the DOE surcharge escrow account at the request of the States until their respective compact commissions are in a position to receive and manage the funds. 
TABLE 2. 1986, 1988, 1990 MILESTONE DISBURSEMENT SUMMARY

\begin{tabular}{|c|c|c|c|c|}
\hline $\begin{array}{l}\text { Compact Regions } \\
\text { and States }\end{array}$ & 1986 Milestone & 1988 Milestone & 1990 Milestone & $\begin{array}{c}\text { Total } \\
\text { Disbursements }\end{array}$ \\
\hline \multicolumn{5}{|l|}{ Appa lachian } \\
\hline De laware & $0.00^{\circ}$ & $0.00^{\circ}$ & $0.00^{\circ}$ & 0.00 \\
\hline Maryland & 16.915 .95 & 92.846 .61 & 377.040 .34 & 486.802 .90 \\
\hline Pennsylvaria & 156.572 .29 & $691,516.91$ & $1,519.047 .26$ & $2,367,136.46$ \\
\hline West Virginia & 0.00 & $0.00^{\circ}$ & $0.00^{\circ}$ & 0.00 \\
\hline Centra: & 77.839 .70 & 574.143 .49 & 848.365 .95 & $1,500,349.14$ \\
\hline Central Midwest & $159,010.35$ & 798.734 .73 & $1.397,076.64$ & 2.354 .821 .72 \\
\hline Midwest & 106.952 .25 & $547,873.41$ & $1.356,453.07$ & 2.011 .278 .73 \\
\hline Northeast & $104,300.92$ & $480,026.66$ & $1,032,121.30$ & $1,616,448.88$ \\
\hline Northwest & 0.00 & $5.00^{b}$ & 0.00 & 0.00 \\
\hline Rocky Mounta in & $230.73^{c}$ & $706.22^{c}$ & 0.00 & 0.00 \\
\hline Southeast & $3.115 .49^{c}$ & $10.875 .16^{d}$ & 0.00 & 0.00 \\
\hline \multicolumn{5}{|l|}{ Southwestern ${ }^{\circ}$} \\
\hline Arizona & 678.10 & 52.643 .19 & 325.775 .01 & 379.096 .30 \\
\hline California & 89.180 .75 & 397.597 .72 & 1.018 .921 .95 & $1,505,700.42$ \\
\hline North Dakota & 0.00 & $391.93^{t}$ & 546.31 & 546.31 \\
\hline South Dakota & 0.00 & $0.00^{\circ}$ & $0.00^{\circ}$ & 0.00 \\
\hline District of Columbia & $256.37^{\circ}$ & 1.910 .47 & 9.850 .45 & 11.760 .92 \\
\hline Maine & 6.312 .29 & $25,899.14$ & $109,478.97^{n}$ & 141.690 .40 \\
\hline Massachusetts & 81.897 .34 & $249.31 i .06$ & 578.542 .99 & 909.757 .39 \\
\hline New Hampshire & 0.00 & $6.993 .58^{\prime}$ & $142.76^{1}$ & 0.00 \\
\hline New York & 94.467 .47 & 322.837 .23 & 912.025 .29 & $1.329,329.99$ \\
\hline Puerto Rico & 0.00 & 0.00 & 0.00 & 0.00 \\
\hline Rhode Is land & $677.49^{\circ}$ & 5.711 .39 & 13.654 .56 & $19,365.95$ \\
\hline Texas & 245.98 & 172.767 .32 & 183.317 .56 & 356.330 .86 \\
\hline Vermont & $16,1 / 1.39$ & $26,681.09^{k}$ & $7,975.82^{\prime}$ & $16,171,39$ \\
\hline TOTAL & $\$ 910.544 .78^{\mathrm{m}}$ & $\$ 4,413,825.33^{\mathrm{m}}$ & $\$ 9.682 .217 .65^{\mathrm{m}}$ & $\$ 15.006,587.76^{m}$ \\
\hline
\end{tabular}


TABLE 2. (continued)

a. All deposits are being held in the interest-bearing Departmert of Energy surcharge escrow account at the request of the State.

b. Refunded to the sited State of Nevada because surcharge furds were collected from generators in other sited compact regions.

c. Refunded to the sited State of Washington because surcharge funds were collected from generators in other sited compact regions.

d. Disbursed $\$ 10,491.13$ to the sited State of Washington and $\$ 384.03$ to the sited State of Nevada to refund surcharges collected from generators in other sited compact regions.

e. The Western Compact was dissolved when the States of California and Arizona formed the Southwestern Compact in July 1988. In February 1989 and July 1989, South Dakota and North Dakota, respectively, joined the Southwestern Compact. At the end of 1990, the Southwestern Compact Commission had not made the necessary provisions to receive rebate disbursements for its member states.

f. Disbursed $\$ 384.37$ to the sited State of Washington and $\$ 7.56$ to the sited State of South Carolina following the Department of Energy's determination of ineligibility.

g. Disbursed to sited State of Washington following the Department of Energy's determination of ineligibility.

h. Refunded an additional $\$ 6,029.24$ to the sited State of South Carolina for surcharge funds collected during a period of noncompliance as determined by the sited States.

i. Disbursed $\$ 6,847.38$ to the sited State of Washington, $\$ 6.71$ to the sited State of Nevada, and $\$ 139.49$ to the sited State of South Carolina following the Department of Energy's determination of ineligibility.

j. Refunded to sited State of Nevada because surcharge funds were collected during a period of noncompliance as determined by the sited States.

k. Disbursed $\$ 1,213.21$ to the sited State of Washington, $\$ 231.72$ to the sited State of Nevada, and $\$ 25,236.16$ to the sited State of South Carolina following the Department of Energy's determination of ineligibility.

1. Refunded to the sited State of South Carolina because surcharge funds were collected during a period of noncompliance as determined by the sited States.

m. Does not include disbursements to the States of Washington. Nevada, or South Carolina because they are sited States. 


\section{SUMMARY OF SURCHARGE REBATE EXPENDITURES DURING 1990}

The nonsited compact regions and nonmember States receiving rebates for the 1986, 1988, or 1990 milestones submitted reports covering expenditures of these funds during calendar year 1990. Expenditures were reported by the following States and compact regions:

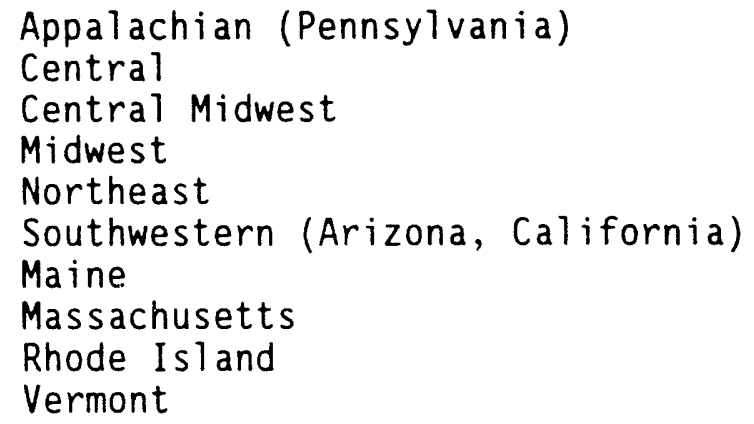

A total of $\$ 4,328,340.44$ was expended by the compact regions and States during 1990. This is two-thirds the amount expended since 1986. The following 1 ist shows the amounts expended during 1990 under each allowable category specified in the Act:

Establish a disposal facility

Mitigate host State impacts

Regulate the disposal facility

Ensure decontamination, decommissioning, closure, and care
$\$ 4,263,340.44$

$65,000.00$

0.00

Expenditures by compact region and State for each allowable category are presented in Table 3 .

\subsection{Surcharge Rebate Expenditures By Nonsited Compact Regions}

\section{Appalachian}

Because the Appalachian Compact Commission had not yet convened at the time disbursements were made following each of the milestones, rebates were made to the individual member States having funds attributed to them except for the States of Delaware and West Virginia, which requested that their funds continue to be held in the surcharge escrow account. Therefore, the member States of Maryland and Pennsylvania submitted individual expenditure reports.

Maryland - No rebate funds were expended in 1990. The funds are being held in a special account by the Maryland Department of Environment. 
TABLE 3. 1990 EXPENDITURES BY EXPENSE CATEGORY

\begin{tabular}{|c|c|c|c|c|c|}
\hline $\begin{array}{c}\text { Nonsited } \\
\text { Compact Regions } \\
\text { and States } \\
\end{array}$ & $\begin{array}{l}\text { Establish } \\
\text { Disposal } \\
\text { Facility }\end{array}$ & $\begin{array}{l}\text { Mitigate } \\
\text { Host State } \\
\text { Impacts } \\
\end{array}$ & $\begin{array}{l}\text { Regulate } \\
\text { Disposal } \\
\text { Facility } \\
\end{array}$ & $\begin{array}{c}\text { Ensure D\&D } \\
\text { Closure } \\
\text { and Care } \\
\end{array}$ & $\begin{array}{c}\text { Total } 1990 \\
\text { Expenditures } \\
\end{array}$ \\
\hline \multicolumn{6}{|l|}{ Appa lachian } \\
\hline Maryland & 0.00 & 0.00 & 0.00 & 0.00 & 0.00 \\
\hline Pennsylvania & $1.806,573.41$ & 0.00 & 0.00 & 0.00 & 1.806 .573 .41 \\
\hline West Virginia & 0.00 & 0.00 & 0.00 & 0.00 & 0.00 \\
\hline Central & 1.034 .498 .00 & 0.00 & 0.00 & 0.00 & 1.034 .498 .00 \\
\hline Centra 1 Midwest & $45,208.22$ & 65.000 .00 & 0.00 & 0.00 & 110.208 .22 \\
\hline Midwest & 234.784 .79 & 0.00 & 0.00 & 0.00 & 234.784 .79 \\
\hline Northeast & 153.348 .55 & 0.00 & 0.00 & 0.00 & $153,348.55$ \\
\hline \multicolumn{6}{|l|}{ Southwestern' } \\
\hline Arizona & 29.130 .96 & 0.00 & 0.00 & 0.00 & 29.130 .96 \\
\hline California & 712.440 .07 & 0.00 & 0.00 & 0.00 & 712.440 .07 \\
\hline North Dakota & 0.00 & 0.00 & 0.00 & 0.00 & 0.00 \\
\hline South Dakota" & 0.00 & 0.00 & 0.00 & 0.00 & 0.00 \\
\hline District of Columbia & 0.00 & 0.00 & 0.00 & 0.00 & 0.00 \\
\hline Ma ine & 54.000 .00 & 0.00 & 0.00 & 0.00 & $54,000.00$ \\
\hline Marsachusetts & 176.867 .60 & 0.00 & 0.00 & 0.00 & 176.867 .60 \\
\hline New York & 0.00 & 0.00 & 0.00 & 0.00 & 0.00 \\
\hline Rhode Is land & 317.45 & 0.00 & 0.00 & 0.00 & 317.45 \\
\hline Texas & 0.00 & 0.00 & 0.00 & 0.00 & 0.00 \\
\hline Vermont & $16,171,39$ & 0.00 & 0.00 & 0.00 & 16.171 .39 \\
\hline TOTAL & $\$ 4,263,340,44$ & $\$ 65.000 .00$ & 0.00 & 0.00 & $\$ 4.328 .340 .44$ \\
\hline
\end{tabular}

a. All deposits are being held in the interest-bearing Department of Energy surcharge escrow account at the request of the state.

b. The Western Compact was dissolved when the States of California and Arizona formed the Southwestern Compact in July 1988. In February 1989 and July 1989. South Dakota and North Dakota, respectively. joined the Southwestern Compact. At the end of 1990, the Southwestern Compact Commission hac not made the necessary provisions to receive rebate disbursements for its member states. 
Pennsylvania - Pennsylvania has expended all of the rebate funds it has received to date. In 1990 , Pennsylvania expended $\$ 1,806,573.41$ to establish a disposal facility. The funds were used for contractor support to develop and submit a disposal facility siting plan. Additional contractor support was used to prepare the annual report to the State legislature, develop regulatory guidance, and facilitate public involvement. The State managed and provided regulatory oversight to their contractors; developed a required quarterly reporting system; reviewed contractors' quality assurance plans; established regulatory procedures; and began implementing its commitments as outlined in the Governor's certification submitted in response to the January 1, 1990, milestone.

\section{Central}

During 1990, Nebraska expended a total of $\$ 1,034,498.00$ to establish a disposal facility. Of this amount, $\$ 859,208.00$ was spent for salaries and administrative expenses of the low-level radioactive waste program and other Nebraska State government support organizations. $\$ 175,290.00$ was used to fund contractor support in developing a low-level radioactive waste management plan, a disposal facility licensing plan, a quality assurance plan, and training staff who will review the upcoming license application.

Remaining funds are being held in the Nebraska State cash fund general account by the Nebraska Department of Treasury for use by the Nebraska Department of Environmental Control in licensing and regulating the proposed disposal facility.

\section{Central Midwest}

The Central Midwest Compact Commission expended $\$ 110,208.22$ in 1990 , $\$ 45,208.22$ of which was used to establish a disposal facility and $\$ 65,000.00$ to mitigate host State impacts.

of the $\$ 45,208.22$ used to establish a disposal facility, the commission spent $\$ 1,767.18$ for expenses associated with conducting commission meetings and hearings. Illinois spent $\$ 9,638.35$ to support participation in various meetings and conferences, including the Technical Coordinating Committee meetings, Low-Level Waste Forum meetings, and the DOE Annual Low-Level Waste Management Conference; $\$ 31,812.70$ to prepare a report on low-level waste import and export restrictions and tracking requirements; and $\$ 1,989.99$ for various administrative expenses related to establishing its disposal facility. The remaining $\$ 65,000.00$ was used to mitigate the impacts of being a host State through grants to potential host communities where sites have been designated for characterization.

The compact commission invests some unexpended funds in federally insured certificates of deposit and U.S. Government securities and deposits the remaining funds in the commission's bank accounts. 


\section{Midwest}

In 1990, the Midwest Compact Commission expended $\$ 234,784.79$ to establish a disposal facility. Of this amount, $\$ 133,261.56$ was used for the salaries, benefits, and office expenses of administering the compact commission; $\$ 57,214.78$ was used for the services of an on-call technical assistance contractor; and $\$ 44,308.45$ was used for legal counsel to the commission.

All funds are held by the Midwest Interstate Low-Level Radioactive Waste Commission in an investment account of Federally insured certificates of deposit and Federal notes.

\section{Northeast}

The Northeast Compact Commission report shows that a total of $\$ 153,348.55$ was expended during 1990 to support the establishment of disposal facilities in each of its two host States.

Of this amount, $\$ 48,700.00$ was used to cover compact commission operating expenses; $\$ 19,106.17$ for consulting and legal fees; and $\$ 85,542.38$ to analyze potential host community mitigation, compensation, and incentive measures, as well as salaries and administrative expenses. The unexpended funds are being held in interest-bearing accounts by the compact commission, and non-interestbearing accounts administered by the Connecticut Office of Policy and Management and the New Jersey Office of Management and Budget.

\section{Southwestern}

Because the Southwestern Compact Commission had not yet convened at the time disbursements were made following the January 1, 1990, milestone, rebates were made to the individual member states having funds attributed to them except for the State of South Dakota, which requested that its funds continue to be held in the surcharge escrow account. Therefore, the member States of Arizona, California, and North Dakota submitted individual expenditure reports.

(NOTE: The Southwestern Compact was formed in July 1988 by the States of Arizona and California. This action dissolved the Western Compact made up of Arizona and South Dakota. In February 1989 and July 1989, South Dakota and North Dakota, respectively, joined the Southwestern Compact.)

Arizona - Arizona used $\$ 29,130.96$ during 1990 to establish a disposal facility. This money was spent to attend low-level radioactive waste meetings and workshops and for various operating expenses necessary to fund compact region support activities and salaries. The remaining funds are in a special account controlled by the Arizona Radiation Regulatory Agency. 
In 1991, the majority of the remaining funds will be turned over to California, the host State for the Southwestern Compact Region. Arizona will retain the remaining portion of the funds in a special account to assist in Southwestern Compact Region activities in accordance with an agreement previously reached with California.

California - California used $\$ 712,440.07$ during 1990 to establish a disposal facility. This money was spent for contractor review of the license application, quality assurance/quality control audits, review of the environmental impact report, study of mixed waste and alternative disposal methods, and low-level radioactive waste program administrative salaries, benefits, and overhead. The remaining funds are being held in a trust fund account administered by the California Department of Health Services.

North Dakota - No rebate funds were expended in 1990. The funds are being held in the Health Department's Operating Fund and are designated for activities of the Southwestern Compact Commission.

\subsection{Surcharge Rebate Expenditures By Nonmember States}

\section{District of Columbia}

No rebate funds were expended in 1990. The funds are held in a general account administered by the Department of Consumer and Regulatory Affairs for regulating, monitoring, and administering the low-level radioactive waste disposal program.

Maine

Maine reported spending $\$ 54,000.00$ during 1990 in support of its efforts to establish a disposa? facility. The Maine Low-Level Radioactive Waste Authority used this money to purchase a computerized graphics information system for screening the State during its site selection process. The Authority will either leave the remaining funds in the current money market account or transfer them to a certificate of deposit for higher interest earnings and future use.

\section{Massachusetts}

The State of Massachusetts spent $\$ 176,867.60$ during 1990 to establish its disposal facility. Of this money, the State spent $\$ 60,935.84$ for legal counsel; $\$ 81,614.33$ in support of the executive director and staff of the LowLevel Radioactive Waste Management Board; and $\$ 34,317.43$ for various administrative expenses. The remaining funds are being held in three state general accounts. The Board uses two operating accounts and the Executive Office of Environmental Affairs uses an account reserved for funds to support development of site selection criteria. 


\section{New York}

No rebate funds were expended in 1990 . The rebate funds are held in a special account administered by the New York State Energy Research and Development Authority. Legislative action is required to reimburse authorized expenditures of designated State agencies from this account.

\section{Rhode Island}

The State of Rhode Island spent $\$ 317.45$ in 1990 to attend Low-Level Waste Forum meetings. The remaining rebate funds are held in a specified State general account controlled by the Department of Environmental Management.

\section{$\underline{\text { Texas }}$}

No rebate funds were expended in 1990. By law, the rebate funds are to be used only with construction funds as they are appropriated by the State legislature. The funds have been deposited in a holding account of the State ireasury.

\section{Vermont}

The State of Vermont has expended all of the rebate funds it has received. During 1990, the State expended $\$ 16,171.39$ to support activities in

establishing its disposal facility. The funds were expended in conducting the business of the Vermont Advisory Commission on Low-Level Radicuctive Waste.

The primary focus of these activities was on developing legislation to satisfy the requirements of the Low-Level Radioactive Waste Policy Amendments Act of 1985. This effort culminated in enactment of Act 296 on June 29, 1990, which sets the State's requirements and schedules for establishing a disposal facility. 


\section{SUMMARY OF EXPENDITURES (1986-1990)}

During the five years from 1986 through 1990, expenditures totaling $\$ 6,567,546.24$ were reported by the following compact regions and States:

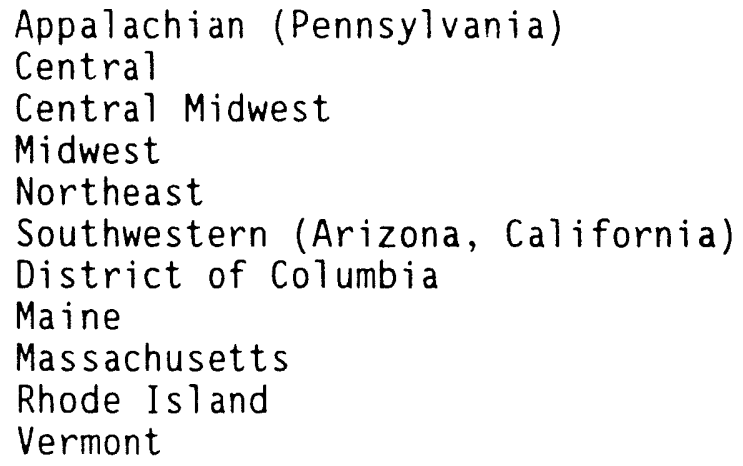

As noted in Table 4, expenditures totaled $\$ 615.95$ in 1986 , $\$ 271,556.68$ in $1987, \$ 656,976.07$ in $1988, \$ 1,310,057.10$ in 1989 , and $\$ 4,328,340.44$ in 1990 . By the end of 1990 , a balance of $\$ 8,439,041.52$ remains unexpended. Table 4 presents summary information on total rebate expenditures and balances by compact region and nonmember State. Table 5 summarizes expenditures by expense category for the years 1986 through 1990. 


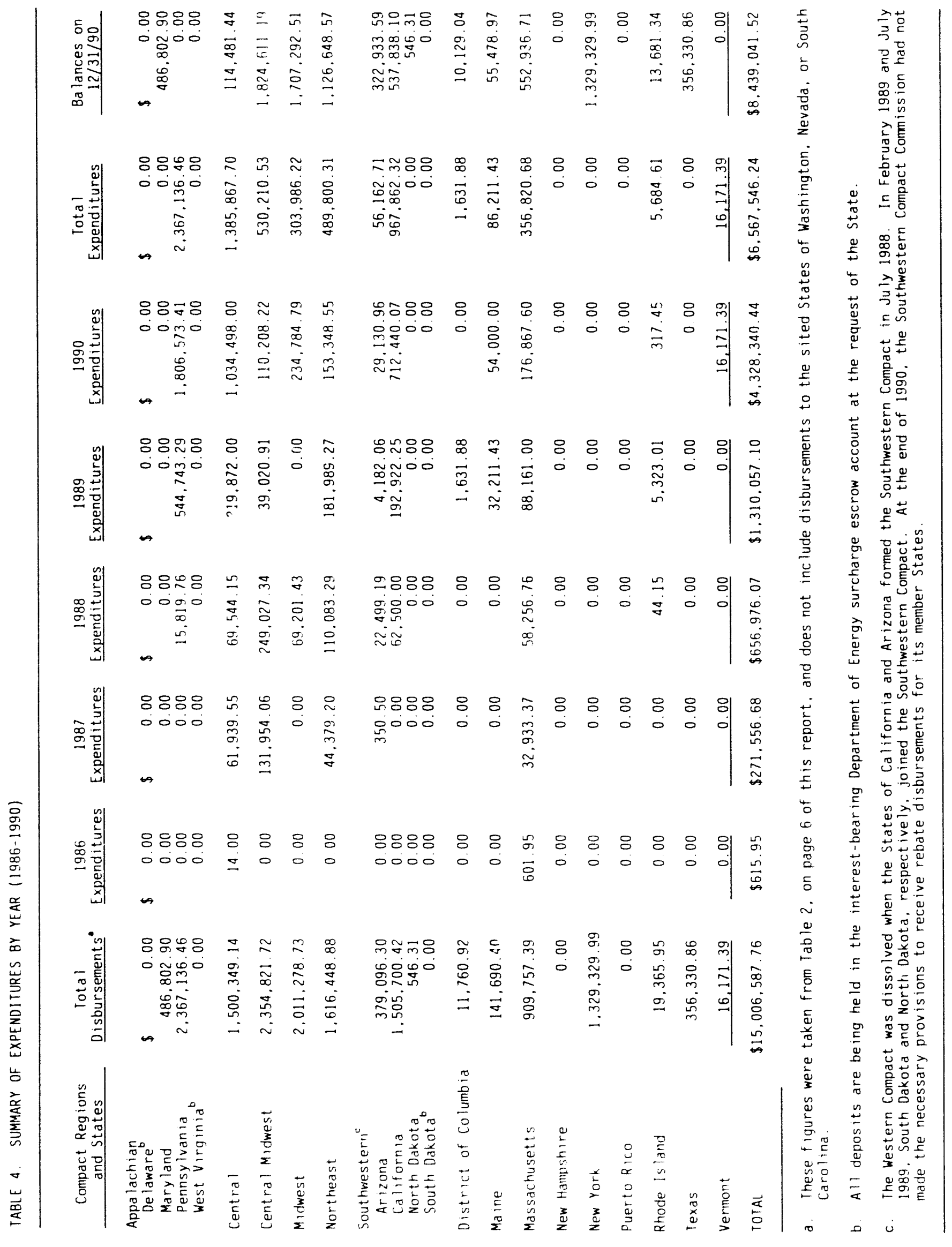


TABLE 5. SUMMARY OF EXPENDITURES BY EXPENSE CATEGORY (1986-1990)

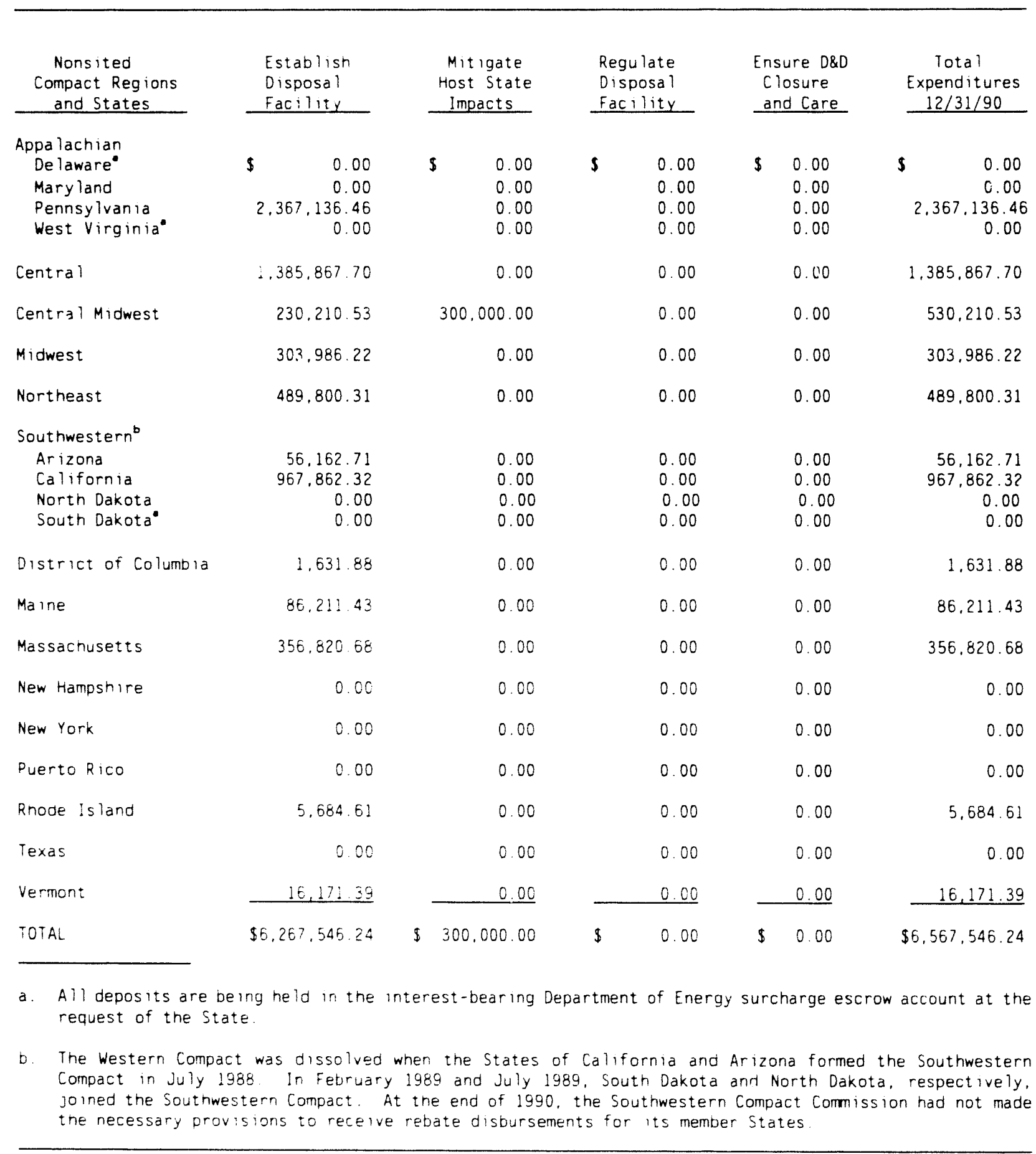



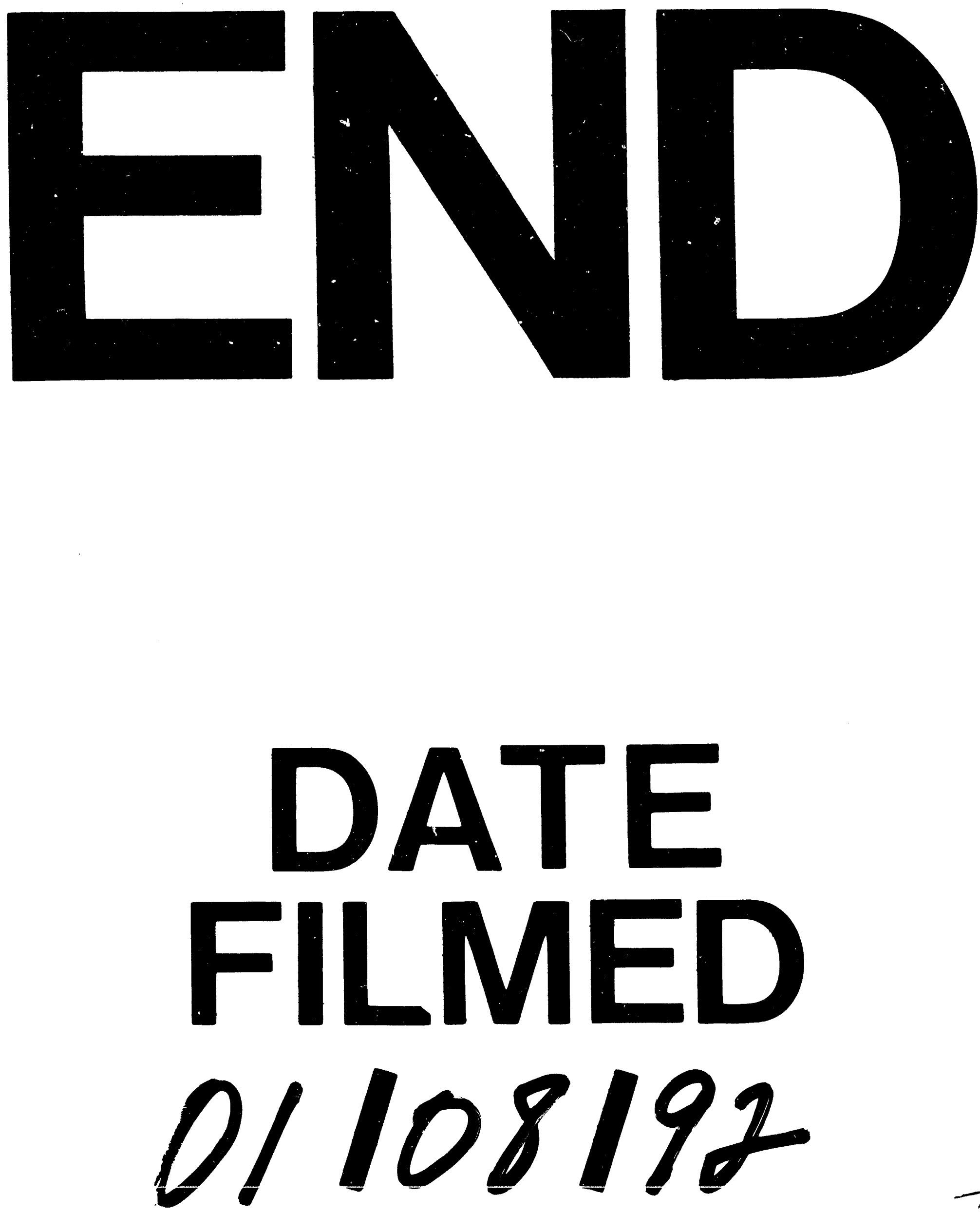
